Jnl of Ecclesiastical History, Vol. 72, No. I, January 202 I. C Cambridge University Press 2020113 doi:10.1017/SoO22046920000093

Note ANd Document

\title{
Dietrich Bonhoeffer's Letter to Mahatma Gandhi
}

\author{
by CLIFFORD GREEN \\ Union Theological Seminary, New York \\ E-mail: cjgreen66o@cs.com
}

This first publication of the newly-found letter to Gandhi from Dietrich Bonhoeffer is a window into his thinking in the early I930s, a time of personal formation and of resistance to National Socialism. Western Christianity needed 'a Christian peace movement', and Bonhoeffer wanted to learn from Gandhi's movement 'the meaning of Christian life, of real community life, of truth and love in reality'. The letter includes Bonhoeffer's critique of Western culture and the Church in Europe and America, his hopes for a Church regenerated by the Sermon on the Mount, and his appreciation and critique of Karl Barth

$\mathrm{M}$ ost readers of the work of Dietrich Bonhoeffer know of his interest in Mohandas Karamchand Gandhi; few realise that it went back to his student days at Tübingen. ${ }^{1}$ Many assume that the Gandhi interest arose in reaction to Hitler, thinking that a pacifist Bonhoeffer wanted to learn non-violent resistance from Gandhi. Reinhold Niebuhr, accordingly, warned Bonhoeffer that it was one thing for Gandhi to resist British colonialism in India with non-violent methods, but that, unlike the British, 'the Nazis would suffer none of the pains of conscience about using violence . . . and organized passive resistance would end in utter failure'. ${ }^{2}$ In fact, although resisting Hitler was one aspect of Bonhoeffer's interest, much more than this drew him to

1 Eberhard Bethge cites Bonhoeffer's conversation 'about Gandhi's personality and work' with his fellow theological student Hans Ulrich Esche in the winter of 1924-5: Dietrich Bonhoeffer. a biography, rev. edn, Minneapolis, MN 2000, 105.

${ }^{2}$ See Dietrich Bonhoeffer to Reinhold Niebuhr, 13 July 1934, Dietrich Bonhoeffer works (English edn), ed. Wayne Whitson-Floyd Jr and Victoria J. Barnett, Minneapolis, MN 1996-2014 (hereinafter cited as DBWE), xiii. 182-4, and Niebuhr's 
Gandhi. Bonhoeffer was motivated by nothing less than his critical assessment of the Church in Western culture, and his deep concern for an authentic, regenerated Christianity focused on the Sermon on the Mount.

There are several letters in the Dietrich Bonhoeffer Works which prove that, after previous unsuccessful attempts, in 1934 Bonhoeffer was determined to visit Gandhi in the near future. ${ }^{3}$ That he himself had personally written to Gandhi is proved by the reply that Bonhoeffer received. Dated 1 November 1934, Gandhi begins: 'I have your letter', and invites Bonhoeffer and his friend to 'come whenever you like', adding that 'you will be staying with me if I am out of prison'. 4 Bonhoeffer did not in fact end up going to visit Gandhi, since his Church called him to return from Britain to Germany to direct the theological training of pastors for the Confessing Church. Bonhoeffer was executed in 1945, and Gandhi was assassinated in 1948.

Meanwhile, Bonhoeffer's letter, of 17 October 1934, languished for many years in a vast collection of correspondence and papers held by Gandhi's secretary Pyarelal Nayar, and, after he died in 1982, by his sister. Although she transferred the papers to the Nehru Memorial Museum and Library in New Delhi, they were not readily available to scholars. Only after her death in 2001 did professional archival preparation begin; eventually the papers became accessible to scholars in two huge batches in 2007 and 2012.5

This information comes from the eminent Indian historian Ramachandra Guha, author of a magisterial two-volume biography of Gandhi. ${ }^{6}$ In the second volume he devotes three pages to Bonhoeffer's interest in Gandhi, quoting in some detail the letter published here.7 Learning about the Bonhoeffer letter from an interview about the biography, I wrote to him requesting a copy. He replied promptly, kindly sent me a scan of the original letter, and requested that I send him what I wrote about Bonhoeffer and the letter.

Bonhoeffer typed his letter, in English, on both sides of two sheets of plain paper; it contains his corrections both typed and handwritten, and concludes with his handwritten signature. The transcription published here is unedited, except for supplying occasional missing letters in words.

response in a 1968 interview with Larry Rasmussen as reported in his Dietrich Bonhoeffer: reality and resistance, Louisville, $\mathrm{Ky} 2005,213$.

3 See, for example, George Bell to Mohandas Gandhi, 22 October 1934, commending Bonhoeffer: $D B W E$ xiii. 225 .

4 DBWE xiii. 229.

5 The original letter is in the personal correspondence files, Gandhi papers, first and second instalments, Nehru Memorial Museum and Library, New Delhi.

6 Ramachandra Guha, Gandhi before India, New York 2013, and Gandhi: the years that changed the world, I9I4-I948, New York 2018. For the archival history of the Pyarelal papers and Bonhoeffer's letter see the latter at pp. xiv-xix.

7 Idem, The years that changed the world, 470-2. 
The letter calls for several comments, beginning with documents. The short theological article that Bonhoeffer mentions is his 'Concerning the Christian idea of God'. Originally a paper for his first semester course at Union Theological Seminary with Eugene Lyman in 1930, it was published in 1932. ${ }^{8}$ Bonhoeffer most likely enclosed with his letter an offprint of the published version which journals in those days commonly gave to their contributors. Whether this was read by Gandhi or survives in the archives has not yet been determined.

Another enclosure mentioned is a letter from C. F. Andrews, an Anglican priest with strong connections to the Quakers. Andrews had known Gandhi from their South Africa days, and his description of Bonhoeffer would be valuable. Given the close friendship between Gandhi and Andrews, it can safely be concluded that Gandhi will have read Andrews's letter which arrived with Bonhoeffer's; presumably it survives in the archives, but that has not yet been confirmed. What is known, thanks again to Ramachandra Guha who quoted it, is that Andrews had already commended Bonhoeffer to Gandhi, five months before Bonhoeffer wrote his own letter. In a letter of 14 May 1934, Andrews told Gandhi that 'If Pastor Bonhoeffer comes to India to enquire about what is being done for World Peace through Ahimsa or Satyagraha, I do hope you will be able to see him. I met him in Switzerland and was greatly impressed with his convictions.'9

As for Bishop George Bell, he had written to Gandhi a few days after Bonhoeffer, on 22 October 1934. Bonhoeffer, he said, 'is intimately identified with the Church opposition in Germany ... and is probably to have charge of the training of Ordination candidates for the Ministry in the future Confessional Church of Germany'. Bell also echoed Bonhoeffer's attraction to intentional Christian community: 'He wants to study community life as well as methods of training. ${ }^{10}$ It is interesting, though, that Bell did not mention learning about non-violent political resistance.

Turning to the content of the letter, how Bonhoeffer chooses to introduce himself to a person whom he holds in high regard is significant. Indeed, the letter is a window into his thinking at a formative time in his life. Here it is only possible to note briefly several important topics by relating them to some other texts in the Bonhoeffer corpus which make the same points. This paves the way for much more detailed research and interpretation.

${ }^{8}$ DBWE x. 45 1 -61; first published in the Journal of Religion xii (1932), 177-85.

9 This is quoted by Guha in The years that changed the world, 470, $948 \mathrm{n}$.6. This letter from C. F. Andrews to Gandhi may explain why Bonhoeffer, in his July letter to Reinhold Niebuhr, writes that 'I am just now waiting for a letter and an invitation from him [Gandhi]': $D B W E$ xiii.184. It seems unlikely that the Andrews letter which Bonhoeffer included with his own in October would only be a copy of the May letter that Andrews mailed directly to Gandhi.

${ }^{10}$ DBWE xiii. 225 . 


\section{Critique of Western culture and the Church.}

While this obviously involves the Nazi regime, now twenty months old, it is actually a much deeper concern that has worried Bonhoeffer for a long time. In 1930, looking back to the First World War, he said that the war had exposed Germany's belief in its power, almightiness and righteousness, its lack of humility, faith and fear of God. ${ }^{11}$ In his 1932 lecture on 'The right to self-assertion', Bonhoeffer contrasted the Indian and Western forms. He described a non-violent protest meeting initiated by Gandhi at which British machine guns mowed down numerous unarmed Indian men, women and children. ${ }^{12}$ The Indians follow the commandment 'You should not destroy any life; suffering is better than living with violence.' The soldiers exemplify the Western form of self-assertion: war and the machine. ${ }^{13}$ The manuscript 'Heritage and decay' in the Ethics, especially the section on nihilism, continues this line of thinking. ${ }^{14}$

Meanwhile, the Protestant Church needed a 'fundamental regeneration', for it had degenerated from its beginnings by turning faith alone ('sola fide') into a lonely dogma, not enlivened by love. ${ }^{15}$ Western Christianity must be very different from what it presently is: 'Western Christianity must be reborn on the Sermon on the Mount.' The same point is made in the letter to Niebuhr: 'It is high time to bring the focus back to the Sermon on the Mount, to some degree on the basis of a restoration of Reformation theology, but in a way different from the Reformation understanding.' ${ }^{16}$

\section{Karl Barth's theological renewal and Bonhoeffer's critique.}

Bonhoeffer praises Barth to Gandhi for having renewed 'the great theological thoughts of the Reformation', but he also believes that something is missing: 'there is no-one to show us the way towards a new Christian life in uncompromising accordance with the Sermon on the Mount'. This type of critical praise is like the Barth critique in Act and being. God's freedom in revelation, Bonhoeffer argues, is not freedom from the world and humanity in divine aseity. Rather, 'God is not free from human beings but for them. Christ is the word of God's freedom. God is present... graspable in the Word within the church.' ${ }^{17}$ In the same vein

${ }^{11}$ DBWE x. $5^{83}$.

${ }^{12} D B W E$ xi. $25^{1}$. In the Jallianwallah massacre of 13 April 1919 over 1,5 oo people were killed or wounded. $\quad{ }^{13} D B W E$ xi. 251-2. $\quad{ }_{14}^{14} D B W E$ vi. 1 $28-32$.

${ }^{15}$ DBWE xiii. 392.

16 DBWE xiii. $183-4$.

${ }^{17} \mathrm{DBWE}$ ii. 90-1, 170. It is not far-fetched to recall Bonhoeffer's remark in the prison letters that Barth was the only one to begin to think along the lines of a 
Bonhoeffer had recently written to Erwin $\mathrm{Sutz}^{18}$ that the Sermon on the Mount was decisive in Christian resistance to National Socialism, though 'Barth's theology ... delayed recognition of this a little while, but certainly made it possible'. ${ }^{19}$ Regarding preaching of the Sermon on the Mount, Bonhoeffer tells Sutz that for himself 'it always comes back to keeping the commandments . . . Following Christ [Nachfolge Christi ${ }^{20}$. . . is not exhausted by our concept of faith. . . . This Winter I'd like to go to India'. ${ }^{21}$ Bonhoeffer sums up his concern in a letter, written after three years of silence, which tells of his 'silent dispute' with Barth 'concerning the interpretation of the Sermon on the Mount and the Pauline doctrine of justification and sanctification'.${ }^{22}$

\section{Peace and resistance}

Bonhoeffer and Gandhi faced different enemies-Fascism and colonial imperialism - but they both sought peace. Gandhi followed a path of consistent non-violence; Bonhoeffer's Christian peace ethic was also a pacifism, but his resistance also included conspiracy and he also approved the killing of Hitler. A comparison of Bonhoeffer and Gandhi on pacifism and resistance would be a valuable contribution. ${ }^{23}$

\section{Witnesses not found in the USA}

The blunt statement 'I went to the U.S.A. to find what I was looking for - but I did not find it' cautions against reading too much into Bonhoeffer's 1930-1 year in New York, at Union Theological Seminary on Morningside Heights and at Abyssinian Baptist Church in Harlem. An apparently simple statement

religionless Christianity, but 'nevertheless did not pursue these thoughts all the way, did not think them through, and ended up with a positivism of revelation': $D B W E$ viii. $363-4$.

${ }^{18}$ Erwin Sutz was his other European companion, with Jean Lasserre, at Union Theological Seminary in New York in 1930-1.

19 DBWE xiii. 135.

20 'Nachfolge Christi' points to the book that he was working on and published in 1937 with the title Nachfolge; this is now translated as Discipleship, in DBWE iv. Its key ideas were first expressed in Bonhoeffer's 1932 lecture 'Christ and peace' (DBWE xii. 258-62), and in the published book, Discipleship, the Sermon on the Mount is its literal centre: $D B W E$ iv. $100-82$.

${ }^{22}$ Bonhoeffer to Karl Barth, 29 Sept. 1936, DBWE xiv. 25²-5.

23 Gandhi's biographer writes that 'When it came to politics, Gandhi was uncompromising in his adherence to non-violence . . Pluralism and non-violence were two core aspects of Gandhi's faith': Guha, The years that changed the world, 261, 263. For Bonhoeffer see Clifford Green, 'Bonhoeffer's Christian peace ethic, conditional pacifism, and resistance', in Michael Mawson and Philip G. Ziegler (eds), The Oxford handbook of Dietrich Bonhoeffer, Oxford 2019, 344-62. 
is actually complex because of different reports from Bonhoeffer. In a Christmas letter to a friend in $193^{\circ}$ he says that he is 'bitterly disappointed' because he has not found the 'cloud of witnesses' (Hebrews xii.1) that he was looking for. ${ }^{24}$ His well-known criticism of preaching in white churches and of theology at the seminary helps to explain his disappointment. Evidently he had hoped that the New World might present him with a new form and modus vivendi of the Church; he therefore wants to learn from Gandhi what he did not find in America, so that the Gandhi visit would be 'the one great occasion in my life to learn the meaning of Christian life, of real community life, of truth and love in reality'.

However, Bonhoeffer's time at Union Seminary had been one of intense discussions with Jean Lasserre and Erwin Sutz about the Sermon on the Mount, the nature of faith and pacifism. ${ }^{25}$ And at Abyssinian Baptist Church he had experienced not only spirited worship and music but also the preaching of Adam Clayton Powell Sr. Powell 'lionized Gandhian non-violent resistance to oppression', teaching that following Jesus meant 'one had to take up the costly, fellow-suffering discipleship of the Sermon on the Mount'. ${ }^{26}$ These experiences, beginning in 1931, Bonhoeffer summed up to Elizabeth Bornkamm in January 1936 as 'a great liberation', freed by 'the Bible, especially the Sermon on the Mount'. ${ }^{27}$ Further research on this period is necessary. The conclusion may be that Bonhoeffer did not find the 'cloud of witnesses' in white churches and theology, but nevertheless his personal and theological experience was rich, liberating and formative.

High regard for the Sermon on the Mount was the meeting point for Bonhoeffer and Gandhi, though the latter read it as a Hindu and the former as a Christian. The letter reveals Bonhoeffer again and again wanting to see faith embodied, 'realised faith', 'a new Christian life in uncompromising accordance with the Sermon on the Mount'. From living with Gandhi and experiencing his movement, Bonhoeffer wanted 'to learn the meaning of Christian life, of real community life, of truth and love in reality'. This remarkable statement in 1934, two years after his 'Christ and peace' lecture ${ }^{28}$ which contained central ideas of his Discipleship, provokes the suggestion that one might read Discipleship hand-in-hand with the letter to Gandhi.

${ }^{24}$ Bonhoeffer to to Helmut Rössler, 11 Dec. 1930, DBWE x. 261.

${ }^{25}$ For Bonhoeffer to Erwin Sutz (who is usually omitted from this context), 28 April 1934, see $D B W E$ xiii. $134^{-6}$; for Lasserre see $D B W E$ viii. $485^{-6}$. Probably the Americans Paul Lehman and Franklin Fisher were also involved in these discussions.

${ }^{26}$ Gary Dorrien, The New Abolition: W. E. B. Du Bois and the black social gospel, New Haven, CT 2015, 437. $\quad{ }^{27}$ DBWE xiv. 134. ${ }^{28}$ DBWE xii. $25^{8-62 .}$ 
APPENDIX

Bonhoeffer's Letter to Gandhi

Pastor Lic. Dietrich Bonhoeffer

23, Manor Mount, S.E. 23. London

October $17^{\text {th }}, 1934$

Revered Mahatmaji!

It is on account of the most distressing situation in the European countries and in my own country, in Germany, that I dare to approach you personally and I hope you will forgive my doing so. I have been waiting for a long time, but now things have advanced so far, that I do not think it justifiable to wait any longer. I know, you have an open ear for every need wherever it be and I trust you will not refuse to give your help and advice to me although you do not know me, and you will forgive my questions.

The great need of Europe and of Germany in particular is not the economic and political confusion, but it is a deep spiritual need. Europe and Germany are suffering from a dangerous fever and are losing both self control and the consciousness of what they are doing. The healing power for all human distress and need, namely Christ's message, is disappointing more and more thinking people on account of its present organisation. There are of course here and there christian individuals who are doing their utmost to move organised Christianity toward a fundamental regeneration, but most of the organised bodies of the Christian Churches would not recognise the real issue. Being myself a christian pastor I find this experience most distressing and depressing. I have no doubt that only true Christianity can help our western peoples to a new and spiritually sound life. But Christianity must be something very different from what it has become in these days.

It is no use to foretell the future which is in God's hands, but if not all signs deceive us, everything seems to work for war in the near future, and the next war will certainly bring the spiritual death of Europe. What we need therefore in our countries is a truly spiritual living christian peace movement. Western Christianity must be reborn on the Sermon on the Mount and here is the crucial point why I am writing to you. From all I know about you and your work after having studied your books and your movement for a few years, I feel we western Christians should try to learn from you, what realisation of faith means, what a life devoted to political and racial peace can attain. If there is anywhere a visible outline towards such attainments, than I see it in your movement. I know, of course, you are not a baptised Christian, but the people whose faith Jesus praised mostly did not belong to the official Church at that time either. We are having great theologians in Germany-the greatest 
of them being to my opinion Karl Barth, whose disciple and friend I am happy to be-they are teaching us the great theological thoughts of the Reformation anew, but there is no one to show us the way towards a new christian life in uncompromising accordance with the Sermon on the Mount. It is in this respect that I am looking up to you for help.

It is the great admiration which I am cherishing for your country, its philosophy and its leaders, for your personal work among the poorest of your fellowmen, for your educational ideals, for your stand for peace and nonviolence, for truth and its force, which has convinced me, that I defifitely should come to India next Winter (together with a friend who is moved by the same ideas and questions - he is a physicist and engineer).* I have been travelling and living all over Europe. I went to the U.S.A. to find what I was looking for-but I did not find it. I do not want to accuse myself of having missed the one great occasion in my life to learn the meaning of Christian life, of real community life, of truth and love in reality. The question which I beg to put before you, is, wether I could be allowed to stay with you in your ashram for a while to study your movement. I do not believe in short interviews, I do think one should live with one another to know each other. I have saved enough money now to pay my voyage, but I should be bound to live on very low expenses in India. Do you think this will be possible? Could one possibly find a family which belongs to your movement with which I could stay and did any sort of tutorial work with the children in compensation? Of course, this is a question of minor importance in comparison with my great desire to know your movement, for which purpose I should be willing to bring any sacrifice what-ever.

I am 28 years old, German, lecturer of Theology in Berlin University, at present Pastor of two german congregations in London, I happen to be international youth secretary of the World Alliance for International Friendship through the Churches, I have been working in the ecumenic movements for a few years and have many good friends there. I have written a few books on the christian doctrine of the Church, of Creation and Sin, and I beg to send you under separate cover a very short theological article in english, written in U.S.A. three years ago.

Now I do not want to trouble you any longer with myself. I am waiting eagerly for an answer from you. Enclosed find a letter of Mr. C. F. Andrews. I have also asked the Bishop of Chichester, Dr Bell, to write a few words about me to you.

* The end of the word 'engineer', and the parenthesis and the period to complete the sentence, have been supplied here. The copy of the third page of Bonhoeffer's letter has several lines ending at the right margin with words missing final letters. They are obvious and uncontroversial. The friend mentioned here is Herbert Jehle. 
I wish to apologize once more for approaching you personally.

I remain, Revered Mahatmaji,

very respectfully,

yours in the Fellowship

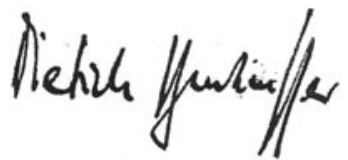

